\title{
The Advent of Ambedkar in the Sphere of Indian Women Question
}

\author{
Poonam Singh'
}

\begin{abstract}
Dr. Bhimrao Ambedkar was a feminist at heart. Contrary to popular perception that he championed the cause of Dalits and dalit women, Babasaheb, as Ambedkar is fondly referred to, worked as a socio-political advocate for Dalit as well as upper caste Indian women concomitantly. In his quest to ensure freedom, equality, and individuality of Indian women, he resorted to the legalized mechanism and proposed sweeping constitutional provisions, famous as the Hindu code Bill, placing women at par with men in matters of inheritance and allowing them freedom to marry outside their caste. Contemplating the predicament and marginalized position of Indian women, he posited that caste and gender are intertwined. To maintain the system of caste, endogamy is a necessary condition that has an immense bearing on women. The imposition of endogamy was made compulsory by the Brahminical hierarchy, which was endorsed by Hindu religious scriptures to ensure women's sustained subjectivity within the same caste groups or varnas. Ironically, the Bill, in Ambedkar's own words was 'killed and died unused and unsung' following which he resigned from then Prime Minister Jawaharlal Nehru's cabinet in 195I but the same bill was passed as four different bills between 1955 and 1956 during Nehru's second term as prime minister (Elancheran, 2018). Unfortunately, Ambedkar's contribution to the Indian women's struggle has not been given its due. This paper attempts to explode the myth of the golden age of Indian womanhood and critiques the role of women reformist organizations in nineteenth century India as well as Ambedkar's yeoman service to Indian women that has largely remained unacknowledged in public discourse.
\end{abstract}

\section{Keywords}

Ambedkar, Hindu Code Bill, Indian women, Feminism, Caste, Gender

'Department of English, Satyawati College, University of Delhi, New Delhi, INDIA E-mail: pkumar.mithi@gmail.com

(C) 2020 Poonam Singh. This is an open access article distributed under the terms of the Creative Commons Attribution License, which permits unrestricted use, distribution, and reproduction in any medium, provided the original author(s) and source are credited. 


\section{Introduction}

Dr B.R. Ambedkar's advocacy of Indian women's rights in the Indian social system puts him on a high pedestal among liberal feminists. Perhaps no other reformer or leader has worked as ardently as Babasaheb to bring about a change in the status of Indian women and ensured freedom, equality, and individuality for them as their legal and constitutional rights. 'Just ask an educated liberal woman of India how they got their rights, irrespective of caste and creed' (Elancheran (2018). As independent India's first law minster, Ambedkar drafted sweeping constitutional provisions, in his famous Hindu Code Bill guaranteeing gender equality in laws mainly pertaining to inheritance and marriage striking at the very roots of 'graded-inequality' of the Hindu caste system. Among the provisions that he envisaged was granting women's right to inheritance and treating them equal to men: "one change is that, the widow, the daughter, the widow of predeceased-son; all are given the same rank as the son in the matter of inheritance. In addition to that, the daughter is also given a share in her father's property: her share is prescribed as half of that of the son" (Ambedkar, 2014, Vol 14, Part one, page 6)

Describing the predicament and marginalized position of Indian women, Ambedkar posited that caste and gender are intertwined. To maintain the system of caste, endogamy is a necessary condition that has an immense bearing on women. The imposition of endogamy was made compulsory by the Brahminical hierarchy, which was endorsed by Hindu religious scriptures to ensure women's sustained subjectivity within the same caste groups or not transgress caste boundaries. In fact, Ambedkar stated that he would measure of progress of a society with the progress of women. Dwelling on the significance the Hindu Code Bill, he said:

To leave inequality between class and class, between sex and sex, which is the soul of Hindu Society untouched and to go on passing legislation relating to economic problems is to make a farce of our constitution and to build a palace on a dung heap. This is the significance I attached to the Hindu Code (Elancheran, 2018).

Ironically, the Bill was stalled in Parliament after a prolonged discussion of four years leading to Ambedkar's resignation as the country's law minister on $27^{\text {th }}$ September 1951, but was passed in the form of four separate bills in 1955 and 1956 during the second term of Prime Minister Jawaharlal Nehru, who had backed the Bill (Ibid).

In asserting the importance of women in society, Ambedkar outstripped his contemporaries who were engaged in nationalist movements or communal politics. He involved women in all of his programmes and asserted that true freedom of an individual lay in equal opportunities for all. Sadly however, this facet of Ambedkar's leadership as a champion of women's rights is grossly undermined. Indian feminists barring a few until very recently have failed to acknowledge Ambedkar as an intellectual who theorized on Indian women's position akin to their demands. Reference to Ambedkar often falls prey to his famous persona of being a Dalit icon only or someone who has worked to emancipate Dalits from their drudgery of lower caste identity. The systematic neglect of Ambedkar's writings is a moral assault on epistemic knowledge and ignorance towards creating a comprehensive Indian academic view.

Dwelling on the idea of Indian women question and the role of Ambedkar, this research paper's methodology is based on a close textual analysis of Ambedkarite canon with archival study and genealogical examination contouring the discourse. It is divided into four major parts. The first draws attention to the myth of the golden age of 
Indian womanhood in the Vedic era. In the second part, the paper critiques nineteenthcentury reformist organizations that brought some relief to Indian women but were unable to give them personhood. The third part highlights the events at the turn of the nineteenth century and arrival of Bhimrao Ambedkar on the Indian political scene. He leaves no stone unturned to address Indian women's issues irrespective of class and caste, and tried hard to enforce a legal mechanism for women's upliftment. In the fourth part, the paper points to the reluctance of upper-class/caste feminist discourse that does not acknowledge Ambedkar and his works to bail out Indian women from their struggle.

The paper also throws light on the reasons behind the potent differences in the marginalization of upper-caste women and Dalit women. The difference between them is maintained by the 'graded inequality' that is an outcome of the graded caste position of the two broad categories from which they come. To guarantee the freedom, equality, and individuality of Indian women, Ambedkar resorted to the legalized mechanism and constitutional provisions. But for his vision and relentless efforts to enforce legal guarantees for the oppressed sections, irrespective of class, creed and gender, much of the rights that upper caste women take for granted today would have remained an elusive dream.

\section{Condition of Hindu Women in Vedic Era: The Myth of the Golden age of Indian Womanhood}

The circulation of popular beliefs that Hindu women's status was as high-ranking as men during the Vedic age is often supported by citing the names of numerous women who might have acted as Brahmavadinis (women who composed hymns in Vedas). Names such as 'Lopamudra, Sulabha Maitreyi, Gargi Kakshivati, Dakshina Prajapathya, Vishvavar, Atreyi, Godha, Apala, Yami Vivasvathi, Romasha Svanya, Aditi Dakshayeni, Ratri Bharadwaja, Vasukra Pathni, Surya Savitri, Indrani, Sarma Devasuni, Urvashi, Shashwati, Angirasi, and Sri Laksha' (epg pathshala, n.page) are mentioned as cases in point. The extension of 'learned Indian Vedic women' myth is not just limited to their composing Vedic hymns as per the Hindu mythological stories, but they are believed to have participated in warfare, social decision-making, and had access to education as well. Such notions have become the markers of an exemplary egalitarian Indian society during the Vedic period to the extent of a fallacy that all Hindu women inhabited an honourable and respectable position in that social system.

These opinions are frequently disseminated and reified in the general perspective. To justify the rapid degradation in the post-Vedic period, regressive rigid Hindu codifications of laws and Muslim invasions of Indian territories are mentioned. However, the stringent Hindu laws which were/are made to 'safeguard' their honour, controlled women's sexuality, freedom, and economic prospects, thus curtailing their autonomy, denying them education, and restricting mobility into well-defined social spaces. As a consequence, such laws reduced their role to childbearing and motherhood, and imposed widowhood on them in the post Vedic period.

In sharp contrast to this utopian projection of Vedic women, Uma Chakravarti (1989), in her essay 'Whatever happened to the Vedic dasi? orientalism, nationalism, and a script for the past' argues that glorification of learned Indian women during the Vedic age is a 'myth' constructed by western-Indian intellectuals bit by bit. The category of respectable learned Hindu women essentially belonged to upper-caste women, she claims pointing out at the end of the essay that 'slave women folk 
were/are unseen/uncounted in those times more profoundly than ever' (Ibid, p.79). Chakravarti puts the spotlight on upscale propaganda of escalating upper-caste Hindu women's position in the Indian social system that was carried out deliberately in sundry stages of history. She simultaneously punctures the notion of a respectable place inhabited by the upper caste Hindu women during the Vedic period. She builds a nuanced argument while classifying Western colonizers and Indian reformists in two different groups. The first group of western scholars investigating Indian history and religious scriptures is further called the first group of orientalists and the second group of orientalists. Uma Chakravarti maintains that the first and the second group of orientalists-William Jones, H.T. Colebrooke, Max Muller, Mrs. Spier and Clarisse Bader-popularised that Indian Vedas were the basis of Indian Hindu religion wherein Hindu women occupied a dignified place. However, these were imaginative conjectures totalled by European women-Mrs. Speier and Clarisse Bader, in awe of the Indian womanhood of their self-sacrificing nature (Ibid, p 43-46). Apart from the awe-struck European women, she includes nationalistic reasons against the British colonizers to build the myth of the golden age of Indian womanhood to suit Indian proto-nationalists' purpose. 'On the one hand, European women intellectuals, Mrs. Speier, Clarisse Bader romanticized Hindu women's valour, mounting their husbands' funeral pyre in Hindu ritualistic practices. On the other hand, Chakravarty underscores that 'it is in Speier's works that one notices vedic women being epitomized as... 'high' status of women in ancient India (Ibid, p 43). Chakravarti unearths such contrived endeavours and establishes her case of how the myth of the golden age of Indian womanhood was created gradually. She argues that it was also done at the convenience of social reformers who 'disregarded the Vedic dasi or slave woman as always, because "recognising her existence would have been an embarrassment to the nationalists" (Ibid, 79) 'The slave women could neither be projected as equal partners nor had adequate caste positions such as Kshatriya to be adorned as a unique avatar of nationalistic warrior woman against the colonizers'. Thus, Uma Chakravarti explodes the popular myth that the Indian Hindu women had a privileged status in the Vedic period and provides us with historical moments in which the construction of this myth was laid, brick by brick, by various forces of diverse locations. Interestingly, V. Geetha ( Geetha, 2011, p 36) validates Chakravarti's disposition on Hindu women from Tamil regions in India. Her endorsement of Chakravarti's argument is that there was not any golden age for Hindu women in the past. She takes the argument a notch higher by applying it to Tamil language politics. Geetha underscores that Tamil women have always remained obscure in political and social lives, as Tamil and Hindi language politics have superseded their interests; thus, Tamil women's issues are systematically dissolved and excluded. Geetha says, 'Tamilness enabled men to be men, facilitated honour-bound comradeship, and cast Tamil men as worthy and aesthetically inclined political actors, it disenabled women from claiming their space in the imagined nation' (Ibid, p. 36).

\section{Acknowledging the Plight of Women: Reformist Movements in Nineteenth Century}

In the early nineteenth century, we do witness specific reformist movements in which prominent figures such as Ram Mohan Roy (1772-1833) along with Mritunjay Vidyalankar (1762-1819) drew attention to Indian women's wretched condition. Ram Mohan Roy sought reformist laws to stop widow immolation, popular as sati, dowry. He also advocated inheritance laws for women through his seminal writing 
Brief Remarks Regarding Modern Encroachment on the Ancient Rights of Female, which essentially highlighted Hindu women's inheritance rights (Ghosh, 1982, p. 375384). In 1819, Roy started Sambād Kaumudi (Kar, 2013. P 3), Bengali magazine in which he vehemently attacked the sati practice - burning of a widow on her husband's funeral pyre, and established the Brahmo Samaj (Sanskrit: Society of Brahma) in 1828 to address social evils prevalent in those days. Apart from Hindu women's property rights, Roy also condemned child marriage, polygamy, and advocated education as a vital component to civilize human behaviour. However, Ram Mohan Roy's efforts in the sphere of women's liberation were confined to taking up the issues of child marriage, widowhood, and sati which were chiefly the problems of Brahmin caste. Therefore Ambedkar makes a distinction on recognising the shallow nature of "social reformation movements in his popular essay Annihilation of Caste as deficient in their conception (Ambedkar, Annihiliation of Caste, n. page) It neither was a reform for Hindu caste system nor included non-Brahmin women, as it did not necessitate reform of caste system as an essential component of such social movements. Ambedkar recognised the selective approach of such unidirectional movements and asserted that

It is necessary to make a distinction between social reform in the sense of reform of Hindu Family and social reform in the sense of reorganisation and reconstruction of the Hindu society... [it] has a [inadequate] relation to widow remarriage, child marriage, etc. while... [it require to] relates to the abolition of caste system. The social conference [exclusively] was concerned itself with the reform of high caste Hindu family. (Ibid, n. page)

Therefore, social movements such as Brahmo Samja, Arya Samaj, Prarthana Samaj, Ramakrishna Mission etc. are insufficient to address the inequities prevalent in Indian society that thrive on the archaic caste system. Another iconoclastic subversive individual was Annie Besant, who remained nonconformist in British Society and brought her revolutionary ideas to India. Nineteenth century is replete with reformist organizations led by enlightened individuals who contained ideas for Indian women liberation. Some such organizations were Arya Samaj, Ramakrishana Mission, Prarthana Samaj, and Young Bengal Movement. Barring the Theosophical Society most of these organizations had its roots in Hinduism and were progressive in a limited sense. None of them focused solely on Indian women's questions. However, Jyotiba Phule (1827-1890) remained different in his ideas while conceiving the Satyashodhak Samaj (Truthseekers' Society) established in 1873. Jyotiba Phule ardently advocated education for women, who were kept out of the ambit of formal educational spheres in most parts of India. In 1848, he started a school for achhut (untouchable) girls. In 1851 he started another school for girls from all castes. He believed that the truitya netra (third eye) could be gained by education only. 'This third eye will help them articulate their position as women in the Dalit community and help develop a critical perspective' (Rege, 2016, p.15-16). Sharmila Rege (2016) draws on Phule's ideology of third eye which 'reimagines education as the trutiya netra that has the possibility to enable the oppressed to understand and transform the relation between power and knowledge' (Ibid). The women from Jyotiba Phule and his wife Savitribai Phule's school recognized the tangible inequality between men and women in the Indian social system; Muktabai- a young Dalit girl from Savitribai Phule's school, crusaded against the caste-based differentiation between untouchable (Dalit) women and upper-caste women in her discreet essay About the Grief of Mahars and Mangs. Another woman member of Satyashodhak Samaj was Tarabai Shinde wrote the famous feminist article Stri Purusha Tulna (A Comparison between Men and Women). These essays now have become historical archives of Indian women's intellectual interventions. Sadly, 
one may observe that despite such social reformation movements way back in the nineteenth century, the status of Indian women remained as that of a dispossessed subaltern in the social system until Ambedkar brought a sharp-toothed legal system to combat adversities inflicted upon Indian women in the early twentieth century.

\section{The Arrival of Ambedkar in the Early Twentieth Century and the Indian Women Question}

Bhim Rao Ambedkar's (1891-1956) critique of Hindu culture/scriptures, Indian social system, caste order is well-known. In his preliminary attempt to understand the Indian social structure, Ambedkar wrote a seminal composition on how caste thrives in India in Castes in India: their mechanism, genesis and development (1916). There is no delay in recognizing how endogamy within different social groups in India is the root cause of maintaining the caste order. Nobody had speculated as cogently as Ambedkar did in his maiden attempt at conceptualizing the Indian hierarchical social order in his essay Caste in India: Their Mechanism, Genesis and Development. The interlocking system of caste and endogamy has resulted, as Ambedkar conceived, in the pernicious and despicable Indian social evil practices of sati practice and forced widowhood. Even though these practices had already been banned in the early nineteenth century, many scholars have not delved into the reasons to unravel the origin of India's evil social practices. Ambedkar undertook an unfaltering scholarly attempt to investigate the reification of the caste structure that was undergirded by the subjugation of Indian women through the imposition of strict endogamous statutes sanctioned by upper caste Indian society's rules (Ambedkar, (Vol 1, 2014) posited a plausible, logical intervention and connects sati, enforced widowhood, girl-child marriage, and endogamy as the offshoots of preserving closed caste units. Ambedkar, thus, theorized that the significant functionality of the caste system depends on the women of that caste group. This makes it imperative that in case of the unforeseen circumstance of widowhood, it has to be taken care of by constructing legal codifications endorsed by religious practices (Ibid). He thus highlighted the distinction between 'surplus man' and 'surplus woman':

I am justified in holding that, whether regarded as ends or as means, Sati, enforced widowhood and girl marriage are customs that were primarily intended to solve the problem of the surplus man and surplus woman in a caste and to maintain its endogamy. Strict endogamy could not be preserved without these customs, while caste without endogamy is a fake... when I say origin of caste, I mean the origin of the mechanism of endogamy (Ambedkar, Vol 1, p 14).

Ambedkar also unearthed the intersection of gender and caste and theorized how these two feed lives into each other to maintain the status quo. The concept of Brahminical patriarchy is the popular conception of gender studies in India. Ambedkar clearly stated that gender discrimination rests on the graded caste system in the hierarchical Hindu fold. He defined the vertical caste hierarchical system and how patriarchy's impact deepens on Hindu women from the lowest caste ladder. He was perhaps, the first Indian intellectual and reformer who theorized on the implications of multi-layered patriarchy on Dalit women. He hypothesized that Dalit women are stationed at the lowest point of the vertically graded caste system that thrives on the superimposition of compulsive endogamy on exogamy.

Ambedkar also understood women's need to be included in the discussion to change their secondary status. The idea of liberation of women to obliterate gender inequality would remain an incomplete project without their participation. Ambedkar 
involved women in all of his programmes and mobilized them to demand equal status with men. For Dalit women, he sought self-dependence at par with their upper-caste counterparts. Therefore, Ambedkarite teachings during the Dalit Mahila Parishads (conference of Dalit women) were relevant for all women across the spectrum. He (Ambedkar, Vol 17, part three 2014, p. 282-83) said:

I made it a point to carry women along with men. That is why you will see that our [c]onferences are always mixed [c]onferences. I measure the progress of a community by the degree of progress which women have achieved...learn to be clean: keep free from all vices. Give education to your children. Instil ambition in them. Inculcate on their minds that they are destined to be great. Remove from them all inferiority complex[es]. Don't be in a hurry to marry: marriage is a liability. You should not impose it on your children unless financially they are able to meet to meet the liabilities arising from marriage. Those who marry bear in mind that to have too any children is a crime. That parental duty lies in giving each child a better start than its parents had. Above all, let each girl who marries stand up to her husband, claim to be her husband's friend and equal, and refuse to be his slave. I am sure if you follow this advice you will bring honour and glory to yourself.

In this excerpt, Ambedkar conceptualized a gynocentric society, wherein patriarchal norms are subverted. Indian women should acquire desirable educational aspirations among their children and also function as equal partners. Asserting the importance of women in society, Ambedkar outstripped his contemporaries who were either engaged with nationalistic movements or communal politics. Such speeches at women's conferences by Ambedkar proved his mettle and pro-women rights approach that the true freedom of an individual lies in equal opportunities for all. Amongst many political and social movements initiated by Ambedkar to ensure an egalitarian society for everyone, he theorized extensively on women's position in the Indian social system. His exclusive writings regarding the development of the women in India are - The Women and the Counter-Revolution, The Hindu code Bill, Castes in India, Manu's Madness or the Brahminic explanation of origin of missed castes. The Change from paternity to maternity: What did the Brahmins wish to gain by, Kali varjya or the Brahmanic art or suspecting the operation of sin without calling it sin, Compulsory matrimony, The Rise and fall of the Hindu women: who was responsible for it?, Progress of the Community is measured by progress of women. These writings establish Ambedkar as one of the greatest thinkers who sympathized with Hindu women's lowly status in the hierarchical Hindu fold.

Undoubtedly, while beginning with his intellectual rhapsody of venturing into caste and interlinking it with women's position in Hindu religious system, Ambedkar powerfully initiated the deliberation on gender questions, which pointed out the exclusive nature of castes and the Hindu scripture Manusmirti as the compounding force behind Indian women's marginalization. Ambedkar wrote The rise and fall of Hindu Woman: who was responsible for it? to challenge Eve's Weekly (21 January 1950) article that held the Buddha responsible for Indian women's downfall. Ambedkar rebutted the Eve's Weekly's claim through his well-researched comparative analysis of the Buddhist texts and then came over to Manusmriti, thereby describing it as one the most regressive texts to allocate subservient roles to India women. The argument made by the Ambedkar was so strong that even today, Manusmiriti's preachings are taken as problematic and precarious for the woman question. Ambedkar was a thorough scholar; he studied ancient Hindu scriptures and stated that 
At one time a woman was entitled to Upanayana (seeking enlightenment or knowledge) is clear from Atharva Veda. From Srauta Sutras (Auxillary texts of Samaveda) it is clear that women could repeat the mantras of the Vedas, and that women were taught to read Vedas. Panini Ashtaadhaya bears testimony to the fact that women attended Gurukul (college) (Rege, 2013, p 125.)

However, such women were very few in numbers and those who were included in religious ceremonies belonging to the upper-caste/class positions, he had pointed. Highlighting the tyrannical rules arrayed in Manusmiriti to regulate Hindu women's conduct, Ambedkar pointed out the machinations of 'Laws of Manu,' which comprise an overbearing precept to control Hindu women as per the men's command. As per the statutes listed in Manusmriti, the Hindu women need to fall under the aegis of paternal order. It says, “"(i)n childhood a female must subject to her father, in youth to her husband, when her lord is dead to her son; a woman must never be independent. She must not seek to separate herself from her father, husband, or sons" (Buhler, 1886, p 33) 'It also pictures the woman as a seductress with low morals. It says, "the nature of women to seduce men in this (world) ... one should not sit in a lonely place with one's mother, sister or daughter" (Ibid, p. 11)

These are the 'Laws of Manu' that have thrust regressive conduct Indian women. Irrespective of the caste position of Indian women, such rules made by Manu are reprehensible. Such rulings become more degenerating as the caste position factored into while reckoning the class position of Indian women.

Ambedkar witnessed the impact of oppressive social conduct and patriarchy on upper-caste Hindu women in general, and the subjugation of Dalit women on multiple levels due to caste, class, and gender variables. He unequivocally opposed patriarchy, and its diverse manifestations and their pernicious bearings on Dalit women. Ambedkar's criticism of Hindu scriptures concerning theorization on uppercaste women and Dalit women in the Indian social system is an exemplary influential work which no one has done as effectively as he did. Urmila Pawar and Meenakshi Moon (2008) in the book We also Made History: Women in Ambedkarite Movement have collected narratives of Dalit women remembering Ambedkar as an inspirational force. These Dalit scholars did a lot of groundwork, travelled extensively across India to excavate the stories of Dalit women narrating how Ambedkar inspired them. Many Dalit women acknowledge that 'Ambedkar endeavoured to bring Dalit women into public life in a new role, as speakers and chairpersons in public meetings, as movers and seconders of resolutions, and its teachers' (Sonalkar, 2008, p 3). Every meeting for Dalit upliftment would necessarily be followed by a Dalit Mahila Parishad [women conference] in which Ambedkar extensively spoke on Dalit women's subjugation and its sanctification by the caste dynamics. The sociological position of Dalit women, as comprehended by Ambedkar, has also been verified by epistemological studies.

The discourse of the erstwhile mainstream upper-caste Indian feminist movements has not only disregarded Ambedkar and his works; they have also rarely accommodated the interests of Dalit women. However, there is some exceptional upper-caste women scholarship such as Sharmila Rege, Uma Chakravarti, and Anupama Rao, who bring the caste angle to resist oppressive patriarchal forces. Taking inspiration from Ambedkar, Dalit intellectuals such as Gopal Guru (1995) theorized on Dalit women's position and tried to locate the essential differences between why 'Dalit Women Talk differently' and what are the concerns that need to be kept in mind while

'representing Dalit women, both at the level of theory and practice, has erupted time and again in the discourse on Dalit women. Dalit women justify the case for talking differently on the basis of external factors (non-Dalit forces) homogenising 
the issues of Dalit women and internal factors (the patriarchal domination within the Dalits) (Ibid, p. 2548-2550)

As a result, the mainstream upper-caste feminism in India has been countered by Dalit women who have asserted that their marginalization is unlike that of upper caste women because Dalit women are offered lower wages for fieldwork, experience unhygienic working conditions, sexual violence, which is an inherent form of caste atrocity than sexual barbarism. The plight of Dalit women becomes more poignant as they get profiled based on their caste. Dalit movement makes their gendered position more visible than their caste identity. Dalit women, in turn, prioritize their selves as members of the Dalit community first and as women later. Badri Narayan (2011, p. 69) points out that:

For Dalit women, their Dalit identity overrides other identities and Dalit women see themselves, first and foremost, as Dalits. Being a woman determines the form and intensity of the violence and oppression which they face, primarily, because they are Dalits. The question of iniquitous gender relations within the Dalits communities gets relegated to second place for them, as they feel it is more important to liberate themselves from being looked upon by the upper castes as being socially and culturally inferior.

Therefore, sexual violence against Dalit women is a gendered form of crime and a caste-oriented one. A google search may open up a pandora's box of sexual crimes that resulted in the victims' death. Dalit women are at a juncture where the liminality of their position makes them vulnerable. Barring Ambedkar, none of the Dalit intellectuals have worked extensively for their rights or hypothesized on Dalit women's conditions and their sufferings resulting from graded patriarchy. Sadly, Dalit movements against caste discrimination have not been vocal about Dalit women's rights as they ought to. Although Dalit movements have replicated a host of upper caste normative principles to eliminate Dalit women's exploitation and warrant their safety from upper-caste men, the rules are formulated precisely as per the whims of upper caste patriarchy. Dalit women are also asked to follow strict rules and not work in public spaces to safeguard community reputation. By emulating upper-caste normative regulations and directives, there is an attempt to domesticate Dalit women, who are also now getting increasingly commodified. For instance, to prevent the exploitation of Dalit women at the hands of upper-caste landlord or community, Charu Gupta observes (Gupta, 2012, p.11):

Chamars [untouchables from Uttar Pradesh region] of Moradabad announced that they would allow their women less liberty of movement. Chamars of Dehradun and Sahranpur started to advocate the wearing of dhotis by their women when cooking food and forbade them to visit bazars to sell grass. A Jatia Chamar Sabha at Meerut attended by over 4000 Chamars, passed a resolution to have their females go into purdah [veil]

Under the garb of such rulings to safeguard Dalit women's sexual exploitation in a casteist society, they have essentially become oppressive legal, social codifications to curb Dalit women's freedom. An onslaught of such rules on Dalit women to subvert their mobility in the public sphere is not a freedom that a Dalit woman would aspire for. These domineering codifications emulate the upper caste ethos of the sanskritization of Dalit women to ape the upper caste patriarchal mechanism. Rege (2013) laments the fact that '[s]ome Dalit feminists also detailed the increasing 'domestication' of wives of Dalit male activists and critically engaged the position of some Dalit men who see women's liberation as being "inauthentic” for Dalit women' (p.17). 
Thus, the liberation of Dalit women remains ineffective and insufficient as they do not completely collapse into the category as lower-caste Dalits, or only as women who are equal to the upper caste women socially and culturally. They assert that Dalit women are not as privileged as upper-caste women and need to be contextualized differently. At the same time, Dalit men are criticized for limiting Dalit women's roles in Dalit households and targeted for perpetuating the patriarchy. Dalit women demystify the claims of Dalit intellectuals such as Kancha Ilaiah (2001) that the 'status of women even among the modern Dalit-Bahujan is more equalitarian than that of the Brahminical women' (Ilaiah, 2001, p 115). Such veneering statements from renowned Dalit intellectuals bring about a discomfort in Dalit women, and they counter it by emphasizing their lives in the domesticated space.

Interestingly, Ambedkar recognized the impact of caste patriarchy, caste position, and internal Dalit patriarchy on Dalit women, as he tried to bail them out from the clutches of such oppressive forces. It also seems quite probable that Ambedkar was aware of the romanticization of Dalit women's bodies. Therefore, he vehemently rejected the idea of Dalit women performing in public plays to generate capital for the Dalit upliftment programmes (Sonalkar, 2008). 'Traditionally, tamasha ${ }^{1}$ was/is a despised and lowly occupation, and women have to struggle constantly to generate income for their family, preserve their honor within'.

Ambedkar disapproved of the commodification of Dalit women's bodies; therefore, they were excluded from public plays, and their part was played by men. He had said, 'I don't want the money raised by making Pawalabai dance' (Ibid, p. 30). In his Mahad Speech in 1927, Ambedkar also urged Dalit women to give up the caste identification markers and inspired them to remain neat and clean in appearance. He motivated Dalit women to relinquish the lower caste traditional way of wearing the sari and donning heavy jewellery to segregate them from upper-caste Brahmin women and mark them as untouchable women (Ibid, 2008). These are only some points that Ambedkar suggested to Dalit women. However, as a disciple of John Dewey, he knew the value of individual freedom, which was equally applicable to women of the upper caste as well. He worked for gender equality and treated women as a person; he 'emphasized, in 1938, that a woman was an individual; therefore, she too must have individual freedom' (Ibid, p.159).

Ambedkar's appeal to Indian women to develop consciousness of their humiliation is an epistemological break. Since he was an intellectual with a vision, he realized that such inspiration might fall flat unless there is a constitutional mechanism to ensure their upliftment. Thus, he laboured incessantly to design a common civil code through the Hindu Code Bill, whereby Indian women were considered an equal individual politically, socially, and constitutionally. In framing the Hindu Code Bill, he proposed a complete overhauling of the Hindu social system. The Bill sought to codify the legal mechanism to address various laws concerning men and women. It sought to alter the order of succession and designed new laws on maintenance, marriage, intercaste marriages, divorce, adoption, and minors and their guardianship. Emphasizing on women's position and the need to guarantee freedom, equality, and dignity to them, he framed the rules of the abolition of the birth right to property, half share for daughters, conversion of women's limited estate to absolute estate, the abolition of caste in marriage matters, and adoption and the principle of monogamy and divorce (Ambedkar, Vol 14, part one, p 5-11). Ambedkar identified so much with the Indian women's cause that he resigned from Nehru's Cabinet when the conservative members rejected the Bill. 'Introduced in the constituent assembly on April 11 1947, the bill was moved by the select committee on Apr 9th, 1948 which was followed by four 
years of debate and remained inconclusive. In his own words "killed and died unused and unsung" (Elancheran, 2018). Eventually, the Hindu Code Bill was passed in Parliament in 1955 and 1956 as four Hindu Code Bills viz. The Hindu Marriage Act, 1955, The Hindu succession Act, 1956, The Hindu Adoptions and Maintenance Act 1956 and The Hindu Minority and Guardianship Act 1956. The upright political position which Ambedkar took for Indian women is unprecedented. He vehemently put his foot down for women's inheritance laws-an idea still accepted as a strange in the Indian social system. Ambedkar wanted to make inheritance laws skewed in favour of Indian women almost a century ago. Since he was, what Gramsci would call, an 'organic' intellectual, he knew women's social upliftment was not possible only by sermons or ideal preaching. Chakravarti, in Gendering Caste: Through a Feminist Lens (2006), makes a logical intervention that Ambedkar critiqued castes as he was 'able to go much further in their understanding of women's oppression' as he had the epistemic privilege of coming from the marginalized sociological position. Thus, he understood that Indian women's emancipation could not come from change of heart only; political/constitutional exigency was as crucial as the social awareness about women's autonomy.

\section{Upper Caste Women's Reception of Ambedkar on Indian Women Question}

In 2016, the Sahitya Akademi ${ }^{2}$ organized a national seminar on Gandhi, Ambedkar, Nehru: Continuities and Discontinuities. The fourth session on the second day of the seminar was committed to 'Women and Equality,' chaired by Rukmini Bhaya Nair and a panel of contemporary women scholars. It provided an opportunity for me to listen to these three noted Indian women scholars' perspectives and their articulation of Gandhian, Nehruvian and Ambedkarite standpoints on Hindu women in Indian culture. The first two speakers from Dalit background were quite vocal about Ambedkarite influence on Hindu women and seemed quite compelling in their recognition of Ambedkar's works. One of the speakers said 'equality means equal freedom for women too, which entails rights and respect for women at domestic space and in the public spaces.' Besides equal economic and political rights, she said 'equality has to be sought in social and cultural spaces as well. And for all this to happen, we need not only changes in the law but also our mindsets, attitudes, and cultural practices.' She concluded her paper with the words of Babasaheb Ambedkar that equality 'for us is a battle not for wealth or for power. It is battle for freedom. It is the battle of reclamation of human personality' (Keer, 1990, p. 351). Another renowned Dalit speaker also tried to map a similar trajectory of women empowerment in the views of Gandhi, Nehru, and Ambedkar vis-à-vis the Hindu women's position. However, I was interested in the third speaker's intention to recognize Ambedkar's contribution towards the upliftment of Indian women as she hailed from an upper-class stratum of Indian Society and had written extensively on gender issues. To my surprise, she spoke only of Jawaharlal Nehru and Gandhi, and omitted Ambedkarite vision on the subject altogether. It is evident that Gandhi has influenced Indian women on the spiritual level, and Nehru, through his egalitarian propaganda, preached the same. However, Ambedkar engineered the legal mechanisms to bring about the required substantial change in the uneven position of Hindu women in Indian society through the constitution. If upper-class women intellectuals do not acknowledge his genderegalitarian endeavours, what can be expected from the non-academic Indian women? Ambedkar's selective exclusion from women empowerment movements and omission 
of his prodigious works regarding partition, economics, and finance is a strategy to reduce his persona as a Dalit icon only.

Indian feminists, until very recently, have failed to acknowledge Ambedkar as an intellectual who theorized on Indian women's position akin to their demands. Reference to Ambedkar often falls prey to his famous persona of being a Dalit leader only or, someone who has worked to emancipate Dalits. The very mention of Ambedkar and his works can prompt anyone to readily sketch him out as a messiah for Dalits. His popularity as a Dalit icon has overshadowed his generic contributions to alter the status quo. It has become almost impossible to extract Ambedkar out of this frame. Since there is not much recognition of Ambedkar's works for women's emancipation, his writings regarding the Indian women's upliftment are not in circulation as potently as his caste-related writings are. The caste-related writings such as Annihilation of caste (1935) and Who Were the Shudras?, Untouchables: who were they and why they became untouchables? are readily available in bookstores or have also been a part of the pamphlet culture of Dalit identity quest.

Although Dalit women have been vocal about Ambedkar's influence on their lives, that remains in a limited scope of education or their lived experiences of atrocities. After having read the Hindu Code Bill, one may say outright that Ambedkar was a radical maverick who fought against the dominant upper-caste social structures and dispensed with women's questions as well. He was a person with multiple visions; one who ventured into all possible fields to eradicate inequality and cement a just society. Ambedkar's writings' systematic neglect is a moral assault on epistemic knowledge and ignorance towards creating a comprehensive Indian academic view. Disregarding Ambedkar's works on Indian women becomes increasingly problematic when the socalled feminist writers do not acknowledge him as one of the prominent protagonists in comparison to Gandhi Gandhi and Jawahar Lal Nehru in the twentieth century.

Unfortunately, Ambedkar is remembered mainly for championing the untouchables' cause, critiquing the hierarchal caste system, and faintly considered a feminist. Ambedkar's progressive approach to bringing about essential changes in women's position in India is commendable because without providing a concrete solution to gender inequality, the upliftment of women would have remained a theoretical construct. Considering Ambedkar's works and political provisions for Indian women, Ambedkar unarguably qualifies as the first feminist of independent India who worked extensively for the rights of both upper-caste women and Dalit women.

\section{Conclusion}

Many Indian intellectuals often take pride in asserting that Indian women's position was as high as men during the Vedic age. The deterioration in their situation is attributed to Manu's regressive codifications in the Hindu religious law book Manusmirti in the post Vedic period and later, to curtail their freedom in the wake of Muslim invasions to protect their honour. These rules became so stringent that Hindu women were burnt alive on their husbands' funeral pyre. Purdah (veil) system, child marriage, enforced widowhood are/were some of the inhumane practices sanctioned by the religion. However, women were/are not a homogenous category. The positions of women are also determined by the caste-groups they belong to.

The most pathetic situation was/is of the women belonging to lower caste groups or Dalits. They have always remained obscure in mainstream Indian feminism. While not many upper caste intellectuals and historians have looked deep into their 
absence from literature, Uma Chakravarti focuses on their omission and in the quest exploded the myth of golden age of Indian women in Vedic period. The references and examples of prominent women intellectuals of Vedic Age, she argues, hailed from the upper echelons of the society. The modern day mainstream feminists also barring a few have ignored the issues of Dalit women. They also tend to ignore Ambedkar's contribution to their cause as a crusader against patriarchy. The legal provisions Ambedkar made for women are mainly beneficial to the upper class/caste women, as inheritance laws could only be practised for wealthy women. Dalit women mostly come from lower economic backgrounds. Divorce law is also most beneficial to upper class/caste women, as in Dalit communities, women are not bound to remain widows and allowed remarriage. Therefore, it is crucial to recognize that although there had been many reformist movements in the nineteenth century to ameliorate the plight of Indian women; however, no one attempted to understand the root cause of the oppressive state of Indian women sanctioned by the Hindu religious scriptures such as Manusmriti. Ambedkar conducted a vital study in this regard in his very first essay, Castes in India: Their Mechanism, Genesis and Development, and observed that strict endogamy over exogamy was primarily to control and curtail the freedom of women. Such theorization paves the way to understand the concept of a graded patriarchal system in which caste patriarchy is paramount, and it recognises sexual exploitation of Dalit women. The remedy to bring about change in Indian women's position, as suggested by Ambedkar, lies in legal mechanism and constitutional provisions and not mere lip service. Attaching jurisprudence to Indian women's rights is unique to Ambedkar and remains unparalleled in the history of the nation. Ambedkar was an extraordinary intellectual and a feminist who tried to ensure equal status for Indian women from all walks of life.

\section{References}

Ambedkar, B. R. (2014) "Hindu Intercaste Marriage Regulating and Validating Bill." Ed. Vasant Moon. Dr. Babsaheb Ambedkar: Writings and Speeches, Vol. 14. Part one. Bombay: Education Department. Goverbnement of Maharashtra. Dr. Ambedkar Foundation: New Delhi.

Ambedkar, B. R. (2014) “ Caste in India: Their Mechanism, Genesis and Development .” Ed. Vasant Moon. Dr. Babsaheb Ambedkar: Writings and Speeches, Vol. 1. Bombay: Education Department. Goverbnement of Maharashtra. Dr. Ambedkar Foundation: New Delhi.

Ambedkar, B. R. (2014) " Progress of the Community is Measured by Progress of Women." Ed. Vasant Moon. Dr. Babsaheb Ambedkar: Writings and Speeches, Vol. 17. Part Three. Bombay: Education Department. Goverbnement of Maharashtra. Dr. Ambedkar Foundation: New Delhi.

Ambedkar, B.R. (2014). "Castes In India: Their Mechanism, Genesis And Developmen.” Ed. Moon, V. Dr. Babasaheb Ambedkar: Writings and Speeches, Vol. 1. Bombay: Education Department, Government of Maharashtra, 1979, Retrieved from http://www.columbia.edu/ itc/mealac/pritchett/00ambedkar/txt_ambedkar_castes.html

Ambedkar, Dr. B.R. (2014). Annihilation of Caste.

https://ccnmtl.columbia.edu/projects/mmt/ambedkar/web/readings/aoc_print_2004.pdf and https://ruralindiaonline.org/library/resource/dr-babasaheb-ambedkar-writings-andspeeches-vol-1/

Buhler, G. Trans. (1886). Manusmriti: The Laws of Manu 1500. www.globalgreybooks.com Retrieved from https://www.islamawareness.net/Hinduism/manusmriti.pdf or

https://www.globalgreyebooks.com/laws-of-manu-ebook.html 
Chakravarti, U. (2006). Theorizing feminism: gendering caste through a feminist lens. Kolkata : Stree. P 122.

Chakravarti, U. (1989). Whatever happened to the Vedic dasi? Orientalism, Nationalism, and a Script for the , in Sangari, K., \& Sudesh Vaid (Eds.) Recasting Women: Essays in Colonial history. New Delhi: Kali for women. Retrieved from http://jan.ucc.nau.edu/ sj6/ Sangari\%20and\%20Vaid\%20Introduction.pdf

Elancheran, S. (2018). Dr Ambedkar's vision of equality through the Hindu Code Bill, Ambedkar King Study Circle, USA, retrieved from https://akscusa.org/2018/04/24/drambedkars-vision- of-equality-through-hindu-code-bill/

Epg Pathshala (n.d.) Women in Vedas: Vedic, epic and puranic culture of India (India culture), epgpathshala, a gateway to all post graduate courses (Ministry of Human resource development). Retrieved from https:/epgp.inflibnet.ac.in/epgpdata/uploads/epgp_content/ S000829IC/ P001497/M015107/ET/14600120574ET.pdf

Geetha, V (2011). The Vedic dasi and other missing women: thinking about nationalism with Uma Chakravarti. In Roy, K. (ed) Insights and Interventions: Essays in Honour of Uma Chakravarti. New Delhi: Primus.

Ghosh, J. C. (ed.) (1982). English Works of Raja Rammohun Roy, Vol III, New Delhi: Cosmo Publications.

Gupta, C. (2012). Representing dalit bodies in colonial North India. NMML Occasional Paper History and Society New Series. Nehru Memorial Museum and Library.

Guru, Gopal. (1995). Dalit women talk differently. Economic and Political Weekly, 30(41/42).

Retrieved from http://www.jstor.org/stable/4403327

Ilaiah, K. (2001). Dalitism vs Brahmanism: The epistemological conflict in history. In Shah, Ghanshyam (Ed) Dalit identity and politics:cultural subordination and the dalit challenge. Vol.2. New Delhi: Sage.

Kar, Samrat (2013). Raja Ram Mohan Roy: Father of Modern India. www.academai.edu, retrieved from https://www.academia.edu/4776146/Ram_Mohan_Roy

Keer, Dhananjay. (1990). From dust to doyen. Dr. Ambedkar: Life and Mission. Mumbai: Popular Prakashan.

Narayan, Badri (2011). The politicization of dalit women. the making of the dalit public in north India: Uttar Pradesh: 1950- Present. New Delhi: Oxford University Press.

Sonalkar, Wandana. (2008). Trans. We also Made history: Women in the Ambedkarite Movement. Urmila Pawar and Meenakshi Moon. New Delhi: Zubaan.

Rege, S. (2013). Against the madness of Manu: B.R. Ambedkar's writings on Brahmanical patriarchy. New Delhi: Navayana.

Rege, S. (2016). Education as Trutiya Netra: towards Phule-Ambedkarite Feminist Pedagogical Practice. In Chakravarti, U. (Ed.) Thinking gender, doing gender: feminist scholarship and practice today. Shimla: Orient Blackswan. P 15-16.

Sahitya Akademi (2015-16). Sahitya Akademi, National academy of letters. Annual Report ( 2015-2016)

\section{Endnotes}

1 Traditional form of Marathi theatre

2 India's state-funded organization for promotion of literature 